\title{
Fruit and vegetable availability: a micro environmental mediating variable?
}

\author{
Russell Jago ${ }^{1, *}$, Tom Baranowski ${ }^{2}$ and Janice C Baranowski ${ }^{2}$ \\ 'Department of Exercise, Nutrition and Health Sciences, Centre for Exercise \& Health, University of Bristol, Tyndall \\ Avenue, Bristol BS8 ITP, UK: ${ }^{2}$ Children's Nutrition Research Center, Department of Pediatrics, Baylor College of \\ Medicine, 1100 Bates Street, Houston, TX 77030, USA
}

Submitted 22 March 2006: Accepted 31 0ctober 2006: First published online 20 February 2007

\begin{abstract}
Objectives: To examine the association between fruit and vegetable (F\&V) availability and consumption, the possible influences on this association, research gaps, and implications for developing strategies to increase F\&V consumption.

Design: Systematic review of studies that have examined associations between F\&V availability and consumption.

Results: Qualitative studies conducted among children and adults indicated that greater availability was associated with greater consumption. This finding was supported by cross-sectional studies among children. Availability was associated with dietary psychosocial variables such as preferences, and it appears that availability may moderate the relationship between these psychosocial variables and consumption. Intervention studies attempting to increase availability have resulted in increased consumption, and availability has predicted change in consumption over an 18month period.

Discussion: Availability appears to be a key proximal determinant of consumption, especially of $\mathrm{F} \& \mathrm{~V}$, and thereby provides a target for change. However, the mechanisms that relate these variables are unclear and there is a need to clarify the direction of causality. We suggest that the possible causal mechanisms may include: (1) availability simply facilitates increased consumption; (2) the visual cues of available food may stimulate consumption; and (3) available food exposure may increase preference, which leads to increased consumption. Each of these possibilities requires close examination, as do policy-level interventions.

Conclusion: F\&V availability is associated with increased consumption. Research that elucidates the mechanisms between availability and intake, and tests policy-level interventions, is needed to advance increased availability as a public health procedure.
\end{abstract}

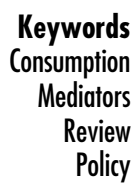

Regular consumption of fruit and vegetables (F\&V) has been associated with a decreased risk of developing many forms of cancer $^{1}$ and coronary heart disease ${ }^{2}$. Yet despite these well-established health benefits, both children ${ }^{3}$ and adults ${ }^{4}$ in the USA and many other Western countries, such as the $\mathrm{UK}^{5,6}$, are not meeting national guidelines for $\mathrm{F} \& \mathrm{~V}$ consumption. Consequently there is a need to develop effective local, regional and national strategies to increase F\&V consumption.

The mediating variable model suggests that changes in a behaviour are a function of changes in the variables that directly impact the behaviour ${ }^{7,8}$. Thus, in order to change F\&V consumption the factors that impact F\&V consumption need to be changed. While many variables such as preferences ${ }^{9}$ and self-efficacy ${ }^{10}$ have been associated with F\&V consumption, perhaps the strongest predictor has been home availability ${ }^{9,11,12}$. Home availability of $F \& V$ is particularly interesting because of its proximal nature to consumption. Availability should be reasonably easy to manipulate and small changes in availability may yield changes in consumption that could provide important health benefits.

The model of home food management processes proposed by Campbell and Desjardins ${ }^{13}$ indicates that food consumption is influenced by a series of hierarchical and interlinked processes that begin with the wider environment, move through household resources (F\&V can only be purchased if there is sufficient money), family provision strategies for food, food acquisition (where the F\&V are purchased), food supply management (how the food is stored, i.e. fresh, frozen or canned), food preparation techniques (how the food is prepared, 
i.e. steamed or deep fried) and end in consumption. Thus home availability plays a central role in this model, which highlights that $\mathrm{F} \& \mathrm{~V}$ are only consumed if purchased, stored and prepared. In order to impact consumption, the food needs to be 'available' to eat.

Different studies have interpreted 'availability' in slightly different ways ${ }^{14}$. US investigators have interpreted availability as the presence of foods in an environment, while Norwegian researchers have included availability items (such as the presence of $\mathrm{F} \& \mathrm{~V}$ in the fridge) in an accessibility measure. This difference can be confusing, as US researchers interpret accessibility as not just whether a food is available in the home but whether it is in a form, location and time that makes consumption easy ${ }^{15}$. In earlier public health research alcohol and tobacco availability measures assessed the extent to which these two drugs could be obtained from different sources such as vending machines and stores ${ }^{16}$. Extrapolation suggests that availability should address the extent to which F\&V are available in a defined location. Consequently, we adopted the definition of Cullen and colleagues ${ }^{15}$ that 'availability concerns whether foods of interest (fruit and vegetables) are present in an environment' (p. 616) such as in the home, school or work cafeteria. With this definition in mind the aims of the present paper are to: (1) illustrate associations between food availability and consumption; (2) highlight how increasing availability has been used to increase consumption; (3) propose the mechanisms by which availability is associated with consumption; and (4) highlight the areas in which further research is required.

\section{Methods}

A literature search was conducted for studies examining F\&V availability and consumption. Computerised searches of PubMed and PsycINFO were conducted in December 2005 using 'availability, accessibility, fruit and vegetables' as keywords. These searches were supplemented by additional follow-up manual searches and examination of the authors' extensive personal records. All of the papers were reviewed to ensure that articles assessed aspects of F\&V availability. Articles that met this criterion were summarised and placed into tables that were grouped by study design.

\section{Results}

\section{Qualitative studies}

Studies that included qualitative reports of associations between F\&V availability and intake are summarised in Table $1^{17-24}$. Home F\&V availability was perceived to be associated with intake among 4 th-6th grade children ${ }^{17,21}$. Similar perceptions were reported among 7 th and 10th grade students in relation to healthy foods (including $\mathrm{F} \& \mathrm{~V})^{20}$. Among Native American adults, qualitative research showed that the limited availability of fresh $\mathrm{F} \& \mathrm{~V}$ on the reservation was perceived to hinder consumption $^{22}$. The availability of $\mathrm{F} \& \mathrm{~V}$ also appears to be influenced by broader social and demographic characteristics. Although F\&V were available in most children's homes, the degree of availability differed by socio-economic status (SES) but not ethnicity ${ }^{18,19,21}$. Children from higher-income homes were more likely to

Table 1 Qualitative studies reporting availability influencing fruit and vegetable (F\&V) consumption

\begin{tabular}{|c|c|c|}
\hline Authors & Study design & Key finding \\
\hline Baranowski et al. (1993) ${ }^{17}$ & Focus groups with 4th and 5th grade students & $\begin{array}{l}\text { Increasing availability of F\&V was } \\
\text { suggested as a means of increasing intake }\end{array}$ \\
\hline Kirby et al. (1995) ${ }^{18}$ & $\begin{array}{l}\text { Focus groups with } 4 \text { th/ } 5 \text { th grade students, parents, } \\
\text { teachers and school food service workers }\end{array}$ & Availability of F\&V differed by SES \\
\hline Cullen et al. (1998) ${ }^{19}$ & Focus groups with urban boy scouts and parents & $\begin{array}{l}\text { F\&V freely available in home, but not sold } \\
\text { as alternative items at school lunch }\end{array}$ \\
\hline $\begin{array}{l}\text { Neumark-Sztainer } \\
\text { et al. }(1999)^{20}\end{array}$ & Focus groups with 7 th and 10th grade students & $\begin{array}{l}\text { Availability associated with consumption and } \\
\text { participants suggested increasing } \\
\text { availability may increase consumption }\end{array}$ \\
\hline Cullen et al. $(2000)^{21}$ & $\begin{array}{l}\text { Focus groups with 4th-6th grade children and } \\
\text { parents from Mexican-American, African-American } \\
\text { and Euro-American schools }\end{array}$ & $\begin{array}{l}\text { Both parents and children reported that } \\
\text { availability of F\&V influenced consumption }\end{array}$ \\
\hline Vastine et al. $(2005)^{22}$ & $\begin{array}{l}\text { Interviews to assess food-purchasing patterns among } \\
\text { Native Americans }\end{array}$ & $\begin{array}{l}\text { Lack of fresh food on the reservation, } \\
\text { particularly } F \& V \text {, hindered consumption. } \\
\text { Participants suggested that increasing } \\
\text { availability on the reservation would aid } \\
\text { consumption }\end{array}$ \\
\hline Molaison et al. $(2005)^{23}$ & $\begin{array}{l}\text { Focus groups with } 42 \text { low-income, } 10 \text { - to 13-year-old } \\
\text { African-Americans to understand influences on F\&V } \\
\text { consumption }\end{array}$ & $\begin{array}{l}\text { F\&V availability reported as influencing } \\
\text { consumption }\end{array}$ \\
\hline Wind et al. $(2005)^{24}$ & $\begin{array}{l}\text { Focus groups with } 9210-11 \text {-year-old Belgian and Dutch } \\
\text { children to understand factors associated with } \\
\text { consumption }\end{array}$ & $\begin{array}{l}\text { Availability of F\&V was low at home and at } \\
\text { school, and this appeared to influence } \\
\text { intake }\end{array}$ \\
\hline
\end{tabular}

SES - socio-economic status. 
have a greater variety of fresh F\&V available while children from lower-income homes were likely to have less choice and more canned and frozen foods ${ }^{18}$. The types of foods available were also different in urban and rural homes ${ }^{18}$. Children reported that $\mathrm{F} \& \mathrm{~V}$ were not sold as alternative items during school lunch, and hence their lack of availability at this location likely hindered consumption ${ }^{19}$. Collectively these studies provide qualitative support for an association between F\&V availability and consumption, but suggest that availability may be affected by broader sociodemographic characteristics such as income and location (urban, rural or reservation).

\section{Cross-sectional studies}

Cross-sectional assessments of F\&V availability are summarised in Table $2^{25-32}$. Hearn and colleagues first reported a positive association between home availability and consumption among 3 rd grade students ${ }^{25}$. The same study also showed that the availability of F\&V at school lunch predicted intake at this specific eating venue. Further, although home availability did not differ by SES or ethnicity, schools that provided a higher number of subsidised lunches (an indicator of SES) tended to offer fewer servings of fruit ${ }^{25}$. F\&V availability also predicted intake among 218 low-income mothers ${ }^{26}$. Thus, these studies and the qualitative research (above) suggest that the associations among availability at home and school and SES are not clear and more research is needed in this area.

Home availability of F\&V was associated with selfreported intake among girls, but not boys ${ }^{15,29}$. The cause of this gender discrepancy is not clear, but the results suggest that targeting increased availability may be less likely to be effective at increasing the consumption of boys and therefore gender-specific strategies may be necessary. A recent study has reported that parent-reported home availability was associated with fruit intake among white adolescents but not among African-American adolescents, while vegetable availability was not associated with intake in either ethnic group ${ }^{32}$. This finding conflicts with the earlier qualitative work and suggests that further examination of ethnic differences is also warranted.

Table 2 Quantitative studies reporting associations between availability of fruit and vegetables (F\&V) and consumption

\begin{tabular}{|c|c|c|}
\hline Authors & Study design & Key findings \\
\hline \multirow[t]{2}{*}{ Hearn et al. $(1998)^{25}$} & $\begin{array}{l}\text { Study 1: F\&V consumption obtained from 3rd } \\
\text { grade children via a food diary and parental } \\
\text { report of home availability/accessibility }\end{array}$ & $\begin{array}{l}\text { Study 1: Home availability/accessibility } \\
\text { (combined measure) predicted consumption } \\
\text { but did not differ by ethnicity, SES or parental } \\
\text { marriage status }\end{array}$ \\
\hline & $\begin{array}{l}\text { Study 2: F\&V consumption at lunch \& staff } \\
\text { assessment }\end{array}$ & $\begin{array}{l}\text { Study 2: Availability of F\&V at school lunch } \\
\text { was associated with consumption }\end{array}$ \\
\hline Quan et al. $(2000)^{26}$ & $\begin{array}{l}\text { Quantitative interview of } 218 \text { low-income mothers } \\
\text { and the factors influencing vegetable consumption }\end{array}$ & Home availability of $F \& V$ predicted intake \\
\hline Kratt et al. $(2000)^{27}$ & $\begin{array}{l}\text { Self-reported F\&V consumption of } 16254 \text { th grade } \\
\text { students. Parental report of availability. Child } \\
\text { measures of F\&V self-efficacy, knowledge \& } \\
\text { outcome expectancies }\end{array}$ & $\begin{array}{l}\text { Consumption of F\&V, knowledge and } \\
\text { self-efficacy of children and parents } \\
\text { increased as availability increased }\end{array}$ \\
\hline Cullen et al. $(2003)^{15}$ & $\begin{array}{l}\text { Self-reported F\&V consumption by } 2255 \text { th-6th } \\
\text { grade students using food records. Child- and } \\
\text { parent-reported availability }\end{array}$ & $\begin{array}{l}\text { F\&V availability predicted consumption, } \\
\text { accounting for } 10 \% \text { of the variance. } \\
\text { Association between availability and intake } \\
\text { moderated by preferences }\end{array}$ \\
\hline $\begin{array}{l}\text { Neumark-Sztainer } \\
\text { et al. }(2003)^{12}\end{array}$ & $\begin{array}{l}\text { Self-reported F\&V intake of among } 3957 \text { middle-school } \\
\text { students and associations with availability, } \\
\text { preferences, attitudes, meal patterns and SES }\end{array}$ & $\begin{array}{l}\text { Availability was strongest predictor of F\&V } \\
\text { intake. Relationships between social support, } \\
\text { meal patterns, food security, SES and } \\
\text { F\&V intake were moderated by availability }\end{array}$ \\
\hline Bere and Klepp (2004) ${ }^{11}$ & $\begin{array}{l}\text { Assessment of correlates of } 1950 \text { th and 7th } \\
\text { grade children's F\&V consumption }\end{array}$ & $\begin{array}{l}\text { A measure that included availability items was } \\
\text { correlated with intake }\end{array}$ \\
\hline Young et al. $(2004)^{28}$ & $\begin{array}{l}\text { Self-reported F\&V consumption of } 366 \text { middle-school } \\
\text { students. Child-reported parenting style, parental } \\
\text { control, parental modelling, availability and self-efficacy }\end{array}$ & $\begin{array}{l}\text { Availability was the strongest }(r=0.525) \\
\text { correlate of } F \& V \text { consumption. Association } \\
\text { between parental modelling and } F \& V \text { intake } \\
\text { moderated by availability }\end{array}$ \\
\hline Hanson et al. $(2005)^{29}$ & $\begin{array}{l}\text { Cross-sectional assessment of middle-school students' } \\
\text { dietary intake }\end{array}$ & $\begin{array}{l}\text { Home availability of } F \& V \text { was associated with } \\
\text { intake among girls but not boys }\end{array}$ \\
\hline Baranowski et al. (2006) $)^{30}$ & $\begin{array}{l}\text { Validation of adult F\&V outcome expectancies scales } \\
\text { and home availability }\end{array}$ & $\begin{array}{l}\text { Outcome expectancy scales correlated } \\
(r=0.18 \text { to } 0.33) \text { with home availability }\end{array}$ \\
\hline Baranowski et al. (2006) ${ }^{31}$ & $\begin{array}{l}\text { Validation of home pantry management practices and } \\
\text { home availability scales }\end{array}$ & $\begin{array}{l}\text { Home pantry management practices correlated } \\
\text { with home availability }(r=0.23 \text { to } 0.37)\end{array}$ \\
\hline Befort et al. $(2006)^{32}$ & $\begin{array}{l}\text { Assessment of correlates of F\&V intake among } \\
\text { African-American and Euro-American } \\
\text { adolescents }(0-19 \text { years of age })\end{array}$ & $\begin{array}{l}\text { Fruit availability was associated with intake } \\
\text { but only among the Euro-American } \\
\text { participants. No association between } \\
\text { vegetable availability and intake among } \\
\text { either group }\end{array}$ \\
\hline
\end{tabular}

SES - socio-economic status. 
Home F\&V availability has been associated with psychosocial predictors of intake. Among 4th grade students participating in the High 5 Alabama programme, mean consumption of F\&V increased with availability, as did knowledge about F\&V and F\&V self-efficacy ${ }^{27}$. Since knowledge and self-efficacy were strong predictors of intake in homes with high availability but not low availability, availability appears to have moderated the associations between self-efficacy, knowledge and F\&V intake $^{27}$. Availability was the strongest predictor of $F \& V$ intake among middle-school students and was also associated with parental control, parental modelling, parental support and self-efficacy ${ }^{28}$. The association between parental modelling and support of F\&V consumption and childhood intake was moderated by home availability. Thus, parents were more likely to consume F\&V and encourage their children to do so if F\&V were available in the home. These two studies demonstrate that availability is not only associated with intake, but it also moderates the association between other psychosocial variables and intake. Home availability of $\mathrm{F} \& \mathrm{~V}$ is therefore both directly and indirectly associated with children's consumption.

One of the most consistent psychosocial predictors of $\mathrm{F} \& \mathrm{~V}$ intake has been preferences ${ }^{9,33}$, but the association between preferences and availability was not clear. Among 225 5th and 6th grade students, availability alone was a significant predictor in a model that accounted for $11 \%$ of the variance in $\mathrm{F} \& \mathrm{~V}$ intake among participants with high preferences for $\mathrm{F} \& \mathrm{~V}^{15}$. However, among those with low preferences, both availability and accessibility were significant predictors in a model that accounted for $23 \%$ of the variance. Thus, the association between intake and availability was moderated by preferences. F\&V availability was associated with taste preferences among middle-school students ${ }^{12}$; when availability was low intake did not differ by preferences, but when preferences were low, intake increased among all groups if F\&V were available. Thus, while both studies support associations between preferences, intake and availability, the nature of the relationships is not clear and requires further clarification.

\section{Cross-sectional associations between dietary fat availability and intake}

Support for the association between availability and intake was provided by similar findings in relation to the availability and consumption of dietary fat. In a random digital dial survey the presence of high-fat foods in the pantry correlated with the percentage of energy consumed from $\mathrm{fat}^{34}$. A similar observation was reported among North American Chinese women ${ }^{35}$. Interestingly, the availability of high-fat foods was associated with both intake and preferences, and preferences moderated the relationship between availability and intake ${ }^{36}$. These studies therefore provide support for the findings of Cullen et al. ${ }^{15}$ and suggest that further examination of these two key variables and their interaction to predict intake of foods is warranted.

\section{Associations between grocery store and restaurant availability and consumption}

Studies that assessed associations between grocery store or restaurant F\&V availability and intake are summarised in Table $3^{37-41}$. In a qualitative study of participants residing in a Scottish Island community, the availability of fresh

Table 3 Studies reporting restaurant and grocery store fruit and vegetable (F\&V) availability and consumption

\begin{tabular}{|c|c|c|}
\hline Authors & Study design & Findings \\
\hline McKie et al. $(1998)^{37}$ & $\begin{array}{l}\text { Focus groups of provision of foods in a } \\
\text { Scottish island community }\end{array}$ & $\begin{array}{l}\text { Participants reported that F\&V were scarcely } \\
\text { available, poor in quality and expensive. } \\
\text { Respondents reported that this was a major } \\
\text { factor in poor diet choices }\end{array}$ \\
\hline Naska et al. $(2000)^{38}$ & $\begin{array}{l}\text { Assessed national-level availability of } \\
\text { F\&V in } 10 \text { European countries and } \\
\text { estimates of consumption }\end{array}$ & Disparity across countries in availability and intake \\
\hline Edmonds et al. $(2001)^{39}$ & $\begin{array}{l}\text { Cross-sectional survey of FJV intake of } \\
90 \text { African-American boy scouts and audit } \\
\text { of randomly selected restaurants and grocery } \\
\text { stores in the census tracts in which } \\
\text { participants resided }\end{array}$ & $\begin{array}{l}\text { Restaurant fruit juice availability associated with } \\
\text { child's juice consumption. Suggestive association } \\
\text { between restaurant vegetable consumption and } \\
\text { child vegetable consumption }\end{array}$ \\
\hline Cummins and Macintyre (2002) ${ }^{40}$ & $\begin{array}{l}\text { Analysed the availability of } 57 \text { foods adequate } \\
\text { for diet in Glasgow and differences by } \\
\text { deprivation area }\end{array}$ & $\begin{array}{l}\text { Orange juice and tinned tomatoes were less available } \\
\text { in lower-income postcodes than in } \\
\text { higher-income places }\end{array}$ \\
\hline Rose and Richards $(2004)^{41}$ & $\begin{array}{l}\text { Secondary analysis of national Food Stamp } \\
\text { Program. Looked at household F\&V use } \\
\text { and associated with distance to the } \\
\text { nearest supermarket }\end{array}$ & $\begin{array}{l}\text { Distance from home to supermarket was inversely } \\
\text { related with F\&V intake. Participants living } \\
>5 \text { miles from supermarket consumed an } \\
\text { average of } 62 \mathrm{~g} \text { of fruit less than those residing } \\
\text { closer to store (approx. } 1 \text { serving per day). } \\
\text { Similar finding for vegetables with } 36 \mathrm{~g} \text { per } \\
\text { person per day increase, approx. } 0.5 \\
\text { servings per day }\end{array}$ \\
\hline
\end{tabular}

FJV - fruit, juice and vegetables. 
F\&V in this extreme location was limited; the foods were expensive and of poor quality; and the participants felt that limited availability was a major factor in their consumption of an undesirable $\operatorname{diet}^{37}$. Availability of fruit, juice and vegetables at restaurants in the census tract within which boy scouts resided was associated with fruit, juice and vegetable consumption ${ }^{39}$. Since Scottish researchers have shown that foods such as orange juice and tinned tomatoes were less available in lower-income postcodes than higher-income places ${ }^{40}$, it is possible that census tract differences are a function of SES. Alternatively, it is possible that differences could be a function of broader environmental features such as location and town planning. This hypothesis is supported by a secondary analysis of the US national Food Stamp Program, in which the distance to the nearest supermarket was inversely associated with F\&V intake ${ }^{41}$. Participants who lived more than 5 miles from the nearest supermarket consumed $62 \mathrm{~g}$ of fruit and $36 \mathrm{~g}$ of vegetables per day less than those residing closer to the store. This equated to approximately 1 serving of fruit and half a serving of vegetables, and thus greater distance was associated with a combined 1.5 fewer servings per day. It is important to note that the association between the availability of F\&V in the local neighbourhood and consumption is consistent with the hierarchical model of Campbell and Desjardins ${ }^{13}$ and provides support for wider environmental features influencing home availability which in turn influences consumption. However, the pathways from local environment availability to home availability to consumption still need to be elucidated.

\section{Intervention studies}

Studies that have either examined how to modify availability to increase consumption or conducted interventions that have focused on increasing availability are summarised in Table $4^{17,33,42-46}$. Focus groups conducted with 4 th and 5 th grade students and teachers ${ }^{17}$ indicated that children influence the types and amounts of F\&V that parents purchase and keep within the home, and thus enhancing children's ability to ask for F\&V (in a polite manner at an appropriate time) may result in increased availability.

Incorporating the development of asking skills (via role play) into an intervention for elementary-school children resulted in a significant 0.2 serving difference in the $F \& V$ intake of intervention over control schools ${ }^{42,43}$. Parental interviews also indicated that $\mathrm{F} \& \mathrm{~V}$ home availability increased as a function of participating in the intervention $^{43}$. Although the small increase in F\&V servings and the relatively small number of schools in the study (the school was the unit of analysis) prevented a mediation analysis, it seems likely that the change in availability mediated the effect of this intervention. A similar finding was reported in

Table 4 Fruit and vegetable (F\&V) intervention and longitudinal studies

\begin{tabular}{|c|c|c|}
\hline Authors & Study design & Findings \\
\hline Baranowski et al. (1993) ${ }^{17}$ & $\begin{array}{l}\text { Focus groups among } 4 \text { th and } 5 \text { th grade } \\
\text { students to understand factors } \\
\text { influencing F\&V consumption }\end{array}$ & $\begin{array}{l}\text { Type and amount of foods purchased by parents } \\
\text { influenced by requests from children, so increasing } \\
\text { children's ability to ask for healthy foods such as } \\
\text { F\&V may increase home availability }\end{array}$ \\
\hline $\begin{array}{l}\text { Baranowski } \\
\text { et al. }(2000)^{42}\end{array}$ & $\begin{array}{l}\text { GIMME } 5 \text { intervention which was designed } \\
\text { to increase F\&V consumption of } \\
\text { elementary-school children. Intervention } \\
\text { included the development of asking skills } \\
\text { for F\&V (to increase home availability) } \\
\text { via role play }\end{array}$ & $\begin{array}{l}\text { Intervention resulted in } 0.2 \text { serving increase in daily } \\
\text { F\&V consumption of participants }\end{array}$ \\
\hline Davis et al. $(2000)^{43}$ & Process evaluation of the GIMME 5 intervention & $\begin{array}{l}\text { Significant treatment by year interaction for fruit } \\
\text { availability suggesting that the intervention } \\
\text { (see above) effect could have been mediated by } \\
\text { changes home availability }\end{array}$ \\
\hline $\begin{array}{l}\text { Baranowski } \\
\text { et al. }(2002)^{44}\end{array}$ & $\begin{array}{l}\text { Intervention to increase F\&V consumption } \\
\text { of urban boy scouts via intervention that } \\
\text { included the development of asking skills } \\
\text { to increase availability }\end{array}$ & $\begin{array}{l}\text { Increase of } 0.8 \text { serving in daily } F \& V \text { intake. Significant } \\
\text { increase in home availability of F\&V }\end{array}$ \\
\hline Perry et al. $(2004)^{45}$ & $\begin{array}{l}\text { Evaluation of a school-based intervention to } \\
\text { increase F\&V consumption of elementary-school } \\
\text { children via increased availability, events } \\
\text { and challenges }\end{array}$ & $\begin{array}{l}0.14 \text { serving per day difference in F\&V consumption } \\
\text { between intervention and control schools at the end } \\
\text { of the study and availability was associated with } \\
\text { consumption at baseline and post-test } \\
\text { (no mediation effects) }\end{array}$ \\
\hline Bere and Klepp (2005) ${ }^{33}$ & $\begin{array}{l}\text { Baseline and 18-month follow-up of } 816 \\
11 \text {-year-old Norwegian children and associations } \\
\text { with combined availability and accessibility measure }\end{array}$ & $\begin{array}{l}\text { Availability predicted intake at both time points. } \\
\text { Changes in availability correlated with } \\
\text { changes in intake }\end{array}$ \\
\hline Bere et al. $(2006)^{46}$ & $\begin{array}{l}\text { Evaluation of policy-level intervention that included } \\
\text { classroom activities, parental information and } \\
\text { participation in Norwegian School Fruit Programme }\end{array}$ & $\begin{array}{l}\text { Although schools and students engaged in } \\
\text { programme and participated in school fruit } \\
\text { programme, no significant intervention effect. } \\
\text { Authors suggest this could be due to a failure } \\
\text { to change availability }\end{array}$ \\
\hline
\end{tabular}


a subsequent intervention that focused on developing asking skills among urban boy scouts, which resulted in a 0.8 serving increase in $\mathrm{F} \& \mathrm{~V}$ intake ${ }^{44}$. The study also reported a significant intervention effect for home availability, suggesting that home availability mediated change in F\&V intake among adolescents. Finally, the authors of a recent Norwegian study ${ }^{46}$ that attempted to increase availability via a curriculum and parent intervention in part attributed their failure to impact consumption to an inability to change home F\&V availability.

\section{Longitudinal association}

Longitudinal support for the association between the availability of $F \& V$ and intake was obtained from a study (Table 4) which showed that a measure including F\&V availability predicted intake at baseline and 18 months later $^{33}$. The study also found that changes in home and school availability and accessibility (combined measures) correlated with changes in intake and that baseline availability moderated the relationship between change in F\&V preferences and intake. Thus, the associations between availability and intake were maintained over time, availability functioned as a mediator of change, and the interactions between preferences and availability were important in understanding and developing strategies to change children's F\&V consumption.

\section{Influences on bome availability}

A recent study of adult food shoppers showed that three measures of the perceived benefits of purchasing $F \& V$ (outcome expectancies) were correlated with home F\&V availability $^{30}$. Measures of social support ${ }^{31}$, pantry management practices $^{31}$ and outcome expectancies ${ }^{30}$ were also correlated with home F\&V availability. Frequent food shopping would enable fresh $\mathrm{F} \& \mathrm{~V}$ to be readily available within the home, while less frequent shopping is likely to result in either less fresh F\&V or more canned and frozen $F \& V^{47}$. The most common food shopping pattern was one big weekly trip to the grocery store with a few additional small trips. However, while 35\% of the participants adopted this pattern, a small but potentially very important $8 \%$ of participants shopped once a month, while $6 \%$ only shopped biweekly ${ }^{47}$. While no significant socio-economic differences were found for overall frequency of food shopping, lower-income respondents were more likely to obtain F\&V from convenience stores while higher-income participants were more likely to purchase $F \& V$ from restaurants for home consumption. These findings suggest that strategies to increase home availability of F\&V could be tailored based on home food management practices. An improved understanding of purchasing patterns and associations with the availability for different types of $\mathrm{F} \& \mathrm{~V}$, as well as participants' preferences for canned, fresh or frozen foods, would facilitate this tailoring as it would allow messages to be created that focus on increasing the availability of the foods that families are more likely to purchase. This improved understanding could also be used to further develop children's asking skills by either developing techniques to encourage their parents to purchase more fresh F\&V (i.e. change their shopping practices) or by encouraging their parents to purchase more canned or frozen foods.

\section{Discussion}

This review demonstrated that the home availability of $\mathrm{F} \& \mathrm{~V}$ was associated with intake among children, adolescents and adults, and the association between intake and consumption was maintained over time. The association between availability and intake was complex and likely to differ by demographic and psychosocial variables. A greater understanding of the mechanisms by which availability may impact consumption would aid the design of more effective programmes that attempt to increase consumption via availability.

A key research issue is to clarify the direction of causality. Do children eat more $F \& V$ because they are available, or do parents make F\&V available because they know their children will eat them? This issue could be addressed by simply providing F\&V to families, assessing what happens to them (e.g. consumed by whom or left spoiled) and evaluating the overall diet (e.g. whether family members eat less other F\&V to compensate for the free food). The issue of the role of preferences could be addressed by systematically varying the $F \& V$ offered to reflect those known to be preferred by the child. Addressing the causality issue will determine whether home availability should be included as a mediating variable in intervention studies.

While there are many factors that could explain the association between availability and consumption there appear to be three likely explanations. First, assuming the direction of causality is from availability to consumption, availability may simply be a facilitating factor: if it is there, people may consume it; it if is not there, they cannot consume it. Wansink and Park ${ }^{48}$ examined the association between container size, taste and popcorn consumption and found that there was 53\% greater consumption from a large container than a small container. There was no significant effect for taste and no taste by container interaction. Thus, the container size functioned as a facilitator for consumption. The same study group also reported that participants used more cooking oil when it was provided in a large container than a small container, but that this relationship was mediated by $\operatorname{cost}^{49}$. Thus, use increased with container size only if the user perceived a cost benefit (e.g. it is ok to use more because it has reduced cost). Applying this finding to $F \& V$ suggests that selling F\&V in larger, cost-saving containers may result in increased consumption. 
Second, external cues such as the sight of freely available F\&V may trigger increased consumption. Consumption of chocolate was influenced by availability and convenience, suggesting that the external cue of seeing the food increased consumption ${ }^{50}$. Extension of this finding to F\&V suggests that the external cues of viewing conveniently available F\&V may at least partially explain the association between availability and consumption. Moreover, storing F\&V in prominent locations, in either the home or place of work, may result in increased consumption.

Third, an alternative (and yet complementary) theory is that the association between availability and consumption is a function of increased exposure. This is consistent with the desensitisation and exposure therapies used in clinical psychology ${ }^{51}$. Although there is some debate as to the mechanisms by which exposure/desensitisation therapy works, repeated exposure to a phobia and anxiety-causing events has resulted in desensitisation to the event. Appetite for pizza was affected by prior exposure to pizza $^{52}$, suggesting that pizza exposure influenced pizza appetite. Thus, if individuals are more regularly exposed to $F \& V$ via increased availability they may be more likely to develop an appetite and taste preference for these foods, which would result in higher intakes. This possibility is supported by research which has shown that increased exposure to a perceived unappetising vegetable resulted in an increase in the preference for that vegetable and increased consumption among 2-6-yearold children ${ }^{53}$. Similar results have also been reported for baby food among 4- to 7-month-old infants ${ }^{54}$. It is important to note, however, that repeated monotonous exposure was associated with lower consumption of a meat sauce than repeated exposure that included variety $^{55}$. Thus, while frequent exposure in the form of F\&V vegetable availability may be important for intake, a strategy that promotes increasing the availability of a wide variety $\mathrm{F} \& \mathrm{~V}$ may be more likely to yield sustained increases in consumption.

In light of this evidence, the social ecological framework may prove useful in furthering the understanding of mechanisms by which availability influences consumption and incorporating increased availability into the design of an intervention. The social ecological framework suggests that a person's behaviour is impacted by the environment in which the behaviour occurs, factors unique to the individual, interpersonal factors whereby the individual interacts with his or her peers, and the interactions between these three broad categories ${ }^{56,57}$. In terms of F\&V, increased availability is likely to interact with personal factors, such as taste and preferences, and interpersonal factors, such as other family members' or peers' consumption and beliefs, to result in increased consumption. Thus, addressing these associations may be an effective strategy to increase consumption. A recent intervention included increased availability of $F \& V$ at school lunch (environment), taste sessions to increase preferences (personal factors) and events (interpersonal factors) such as challenge weeks to promote F\&V consumption in the school. The study resulted in a 0.14 serving per day $(P=0.03)$ difference in the $\mathrm{F} \& \mathrm{~V}$ consumption of intervention and control schools. While this difference was small, the study provided insights into how it is possible to effectively incorporate increased availability into a social ecological framework intervention, which warrants further examination.

\section{Future research directions}

While highlighting associations between F\&V availability and consumption this review raises a number of issues that require further consideration. A key task is to gain a greater understanding of the mechanisms by which availability impacts consumption. While we have proposed some mechanisms, they are untested in relation to F\&V. Empirical testing of these associations is necessary to develop more effective strategies to transform increased availability into increased consumption.

The biggest gap in this literature is the assessment of policy-level interventions. Norwegian research has shown that elementary students attending a school that provided a free piece of fruit per day consumed an extra 0.7 serving of fruit compared with students in a paying school fruit programme and 0.9 of a serving more than participants without a school fruit programme ${ }^{58}$. US Senator Tom Harkin instituted the US Department of Agriculture's Fruit and Vegetable Pilot Program (FVPP) to distribute free F\&V to schools in a number of states ${ }^{59}$. The FVPP evaluation was positive, but included mostly qualitative testimonial data. It is not clear if the FVPP led to increased F\&V intake among children or displaced F\&V that would have otherwise been eaten at home. However, there is a shortage of studies that have examined policy-level interventions to increase the availability of $\mathrm{F} \& \mathrm{~V}$ within the wider community. It is also not clear whether governmental sponsoring of reduced-price $\mathrm{F} \& \mathrm{~V}$ will increase home availability and consumption of these foods. Moreover, while it is possible that some of the costs could be offset by increased demand, the economics of such approaches are not clear. At a more local level, more research is needed to understand how to increase availability in work locations, what has to be done to increase availability in work canteens, how work refreshment areas can most effectively promote $\mathrm{F} \& \mathrm{~V}$, what the barriers to promotion are and how they can be overcome.

\section{Conclusions}

This review has highlighted that the availability of F\&V is associated with intake, that the relationship is sustained over time, and that changes in availability are likely to mediate changes in consumption. The review has also 
placed availability in the context of home food shopping practices to demonstrate the broader impacts on home availability. Thus, although the manipulation of availability is likely a key method for obtaining increases in consumption, a greater understanding of the mechanisms involved in the association and the effect of policy-level interventions is needed to appreciate the feasibility of public health interventions that focus on increasing F\&V availability.

\section{Acknowledgements}

Sources of funding: This paper is a publication of the United States Department of Agriculture/Agricultural Research Service (USDA/ARS) Children's Nutrition Research Center, Department of Pediatrics, Baylor College of Medicine, Houston, Texas, and has been funded in part with federal funds from the USDA/ARS under Cooperative Agreement No. 58-6250-6001. The contents of this publication do not necessarily reflect the views or policies of the USDA, nor does mention of trade names, commercial products or organisations imply endorsement from the US government.

Conflict of interest declaration: None declared.

Authorship responsibilities: All authors participated in the conception of the paper, the search of journals and personal records, abstracting of papers, and drafting and editing of the manuscript.

\section{References}

1 Riboli E, Norat T. Epidemiologic evidence of the protective effect of fruit and vegetables on cancer risk. American Journal of Clinical Nutrition 2003; 78(Suppl. 3): 559S-69S.

2 Joshipura KJ, Hu FB, Manson JE, Stampfer MJ, Rimm EB, Speizer FE, et al. The effect of fruit and vegetable intake on risk for coronary heart disease. Annals of Internal Medicine 2001; 134(12): 1106-14.

3 Brady LM, Lindquist CH, Herd SL, Goran MI. Comparison of children's dietary intake patterns with US dietary guidelines. British Journal of Nutrition 2000; 84(3): 361-7.

4 Stables GJ, Subar AF, Patterson BH, Dodd K, Heimendinger J, Van Duyn MA, et al. Changes in vegetable and fruit consumption and awareness among US adults: results of the 1991 and 19975 A Day for Better Health Program surveys. Journal of the American Dietetic Association 2002; 102(6): 809-17.

5 Wardle J, Jarvis MJ, Steggles N, Sutton S, Williamson S, Farrimond $\mathrm{H}$, et al. Socioeconomic disparities in cancer-risk behaviors in adolescence: baseline results from the Health and Behaviour in Teenagers Study (HABITS). Preventive Medicine 2003; 36(6): 721-30.

6 Hoare J, Henderson L, Bates CJ, Prentice A, Birch M, Swan G, et al. The National Diet and Nutrition Survey: Adults aged 19 to 64 years - Summary Report. London: Office for National Statistics, 2004.

7 Baranowski T, Anderson C, Carmack C. Mediating variable framework in physical activity interventions. How are we doing? How might we do better? American Journal of Preventive Medicine 1998; 15(4): 266-97.
8 Baranowski T, Lin LS, Wetter D, Resnicow K, Hearn MD. Theory as mediating variables: why aren't community interventions working as desired? Annals of Epidemiology 1997; 7(Suppl.): S89-S95.

9 Blanchette L, Brug J. Determinants of fruit and vegetable consumption among 6-12-year-old children and effective interventions to increase consumption. Journal of Human Nutrition and Dietetics 2005; 18(6): 431-43.

10 Steptoe A, Perkins-Porras L, McKay C, Rink E, Hilton S, Cappuccio FP. Psychological factors associated with fruit and vegetable intake and with biomarkers in adults from a lowincome neighbourhood. Health Psychology 2003; 22(2): $148-55$.

11 Bere E, Klepp KI. Correlates of fruit and vegetable intake among Norwegian schoolchildren: parental and self-reports. Public Health Nutrition 2004; 7(8): 991-8.

12 Neumark-Sztainer D, Wall M, Perry C, Story M. Correlates of fruit and vegetable intake among adolescents. Findings from Project EAT. Preventive Medicine 2003; 37(3): 198-208.

13 Campbell CC, Desjardins E. A model and research approach for studying the management of limited food resources by low income families. Journal of Nutrition Education 1989; 21: $162-71$.

14 Bryant M, Stevens J. Measurement of food availability in the home. Nutrition Reviews 2006; 64(2): 67-76.

15 Cullen KW, Baranowski T, Owens E, Marsh T, Rittenberry L, de Moor C. Availability, accessibility, and preferences for fruit, $100 \%$ fruit juice, and vegetables influence children's dietary behavior. Health Education E Behavior 2003; 30(5): 615-26.

16 Klepp KI, Jones-Webb R, Wagenaar AC, Short B, Murray DM, Forster JL. Measurement of alcohol and tobacco availability to underage students. Addictive Behaviors 1996; 21(5): 585-95.

17 Baranowski T, Domel S, Gould R, Baranowski J, Leonard S, Treiber $\mathrm{F}$, et al. Increasing fruit and vegetable consumption among 4 th and 5 th grade students: results from focus groups using reciprocal determinism. Journal of Nutrition Education 1993; 25: 114-20.

18 Kirby SD, Baranowski T, Reynolds KD, Taylor G, Binkley D. Children's fruit and vegetable intake: socioeconomic, adultchild, regional and urban-rural differences. Journal of Nutrition Education 1995; 27: 261-71.

19 Cullen KW, Baranowski T, Baranowski J, Warnecke C, de Moor C, Nwachokor A, et al. '5 A Day' achievement badge for urban boy scouts: formative evaluation results. Journal of Cancer Education 1998; 13(3): 162-8.

20 Neumark-Sztainer D, Story M, Perry C, Casey MA. Factors influencing food choices of adolescents: findings from focus-group discussions with adolescents. Journal of the American Dietetic Association 1999; 99(8): 929-37.

21 Cullen KW, Baranowski T, Rittenberry L, Olvera N. Socialenvironmental influences on children's diets: results from focus groups with African-, Euro- and Mexican-American children and their parents. Health Education Research 2000; 15(5): 581-90.

22 Vastine A, Gittelsohn J, Ethelbah B, Anliker J, Caballero B. Formative research and stakeholder participation in intervention development. American Journal of Health Behavior 2005; 29(1): 57-69.

23 Molaison EF, Connel CL, Stuff JE, Yadrick MK, Bogle M. Influences on fruit and vegetable consumption by lowincome black American adolescents. Journal of Nutrition Education and Behavior 2005; 37(5): 246-51.

24 Wind M, Bobelijn K, De Bourdeaudhuij I, Klepp K. A qualitative exploration of determinants of fruit and vegetable intake among 10- and 11-year-old children in the low countries. Annals of Nutrition \& Metabolism 2005; 49(4): 228-35.

25 Hearn MD, Baranowski T, Baranowski J, Doyle C, Smith M, Lin $1 S$, et al. Environmental influences on dietary behaviour 
among children: availability and accessibility of fruits and vegetables enable consumption. Journal of Health Education 1998; 29(1): 26-32.

26 Quan T, Saloman J, Nitzke S, Reicks M. Behaviours of lowincome mothers related to fruit and vegetable consumption. Journal of the American Dietetic Association 2000; 100(5): 567-9.

27 Kratt P, Reynolds K, Shewchuk R. The role of availability as a moderator of family fruit and vegetable consumption. Health Education E Behavior 2000; 27(4): 471-82.

28 Young EM, Fors SW, Hayes DM. Associations between perceived parent behaviours and middle school student fruit and vegetable consumption. Journal of Nutrition Education and Behavior 2004; 36(1): 2-12

29 Hanson NI, Neumark-Sztainer D, Eisenberg ME, Story M, Wall M. Associations between parental report of the home food environment and adolescent intakes of fruits, vegetables and dairy foods. Public Health Nutrition 2005; 8(1): 77-85.

30 Baranowski T, Watson K, Missaghian M, Broadfoot A, Baranowski J, Cullen KW, et al. Parent outcome expectancies for purchasing fruit and vegetables: a validation. Public Health Nutrition 2007; 10(3).

31 Baranowski T, Missaghian M, Watson K, Broadfoot A, Cullen $\mathrm{K}$, Nicklas T, et al. Home fruit, juice and vegetable pantry management and availability scales: a validation. Appetite 2006; submitted.

32 Befort C, Kaur H, Nollen N, Sullivan D, Nazir N, Choi WS, et al. Fruit, vegetable, and fat intake among non-Hispanic Black and non-Hispanic white adolescents: associations with home availability and food consumption settings. Journal of the American Dietetic Association 2006; 1063): 367-73.

33 Bere E, Klepp KI. Changes in accessibility and preferences predict children's future fruit and vegetable intake. International Journal of Behavioral Nutrition and Physical Activity 2005; 2: 15.

34 Patterson RE, Kristal AR, Shannon J, Hunt JR, White E. Using a brief household food inventory as an environmental indicator of individual dietary practices. American Journal of Public Health 1996; 87(2): 272-5.

35 Satia JA, Patterson RE, Kristal AR, Hislop TG, Pineda M. A household food inventory for North American Chinese. Public Health Nutrition 2001; 4(2): 241-7.

36 Raynor HA, Polley BA, Wing RR, Jeffery RW. Is dietary fat intake related to liking or household availability of high- and low-fat foods? Obesity Research 2004; 12(5): 816-23.

37 McKie L, Clark GM, Maclellan M, Skerratt S. The promotion of healthy eating: food availability and choice in Scottish island communities. Health Education Research 1998; 13(3): 371-82.

38 Naska A, Vasdekis VG, Trichopoulou A, Friel S, Leonhauser $\mathrm{IU}$, Moreiras $\mathrm{O}$, et al. Fruit and vegetable availability among ten European countries: how does it compare with the 'fivea-day' recommendation? DAFNE I and II projects of the European Commission. British Journal of Nutrition 2000; 84(4): 549-56.

39 Edmonds J, Baranowski T, Baranowski J, Cullen KW, Myres D. Ecological and socioeconomic correlates of fruit, juice, and vegetable consumption among African-American boys. Preventive Medicine 2001; 32(6): 476-81.

40 Cummins S, Macintyre S. A systematic study of an urban foodscape: the price and availability of food in Greater Glasgow. Urban Studies 2002; 11: 2115-30.
41 Rose D, Richards R. Food store access and household fruit and vegetable use among participants in the US Food Stamp Program. Public Health Nutrition 2004; 7(8): 1081-8.

42 Baranowski T, Davis M, Resnicow K, Baranowski J, Doyle C, Lin LS, et al. Gimme 5 fruit, juice, and vegetables for fun and health: outcome evaluation. Health Education \& Behavior 2000; 27(1): 96-111.

43 Davis M, Baranowski T, Resnicow K, Baranowski J, Doyle C, Smith M, et al. Gimme 5 fruit and vegetables for fun and health: process evaluation. Health Education \& Behavior 2000; 27(2): 167-76.

44 Baranowski T, Baranowski J, Cullen KW, deMoor C, Rittenberry L, Hebert D, et al. 5 a day Achievement Badge for African-American Boy Scouts: pilot outcome results. Preventive Medicine 2002; 34(3): 353-63.

45 Perry CL, Bishop D, Taylor GL, Davis M, Story M, Bishop SC, et al. A randomized school trial of environmental strategies to encourage fruit and vegetable consumption among children. Health Education E Behavior 2004; 31(1): 65-76.

46 Bere E, Veierod MB, Bjelland M, Klepp KI. Outcome and process evaluation of a Norwegian school-randomized fruit and vegetable intervention: Fruits and Vegetables Make the Marks (FVMM). Health Education Research 2006; 21(2): 258-67.

47 Yoo S, Baranowski T, Missaghian M, Baranowski J, Cullen K, Fisher J, et al. Food-purchasing patterns for home: a grocery store-intercept survey. Public Health Nutrition 2006; 9(3): 384-93.

48 Wansink B, Park SB. At the movies: how external cues and perceived taste impact consumption volume. Food Quality and Preference 2001; 12: 69-74.

49 Wansink B. Can package size accelerate usage volume? Journal of Marketing 1996; 60: 1-14.

50 Painter JE, Wansink B, Hieggelke JB. How visibility and convenience influence candy consumption. Appetite 2002; 38(3): $237-8$

51 Tryon WW. Possible mechanisms for why desensitization and exposure therapy work. Clinical Psychology Review 2005; 25(1): 67-95.

52 Marcelino AS, Adam AS, Couronne T, Koster EP, Sieffermann JM. Internal and external determinants of eating initiation in humans. Appetite 2001; 36(1): 9-14.

53 Wardle J, Cooke LJ, Gibson EL, Sapochnik M, Sheiham A, Lawson M. Increasing children's acceptance of vegetables; a randomized trial of parent-led exposure. Appetite 2003; 40(2): $155-62$.

54 Birch LL, Gunder L, Grimm-Thomas K, Laing DG. Infants' consumption of a new food enhances acceptance of similar foods. Appetite 1998; 30(3): 283-95.

55 Zandstra EH, de Graaf C, van Trijp HC. Effects of variety and repeated in-home consumption on product acceptance. Appetite 2000; 35(2): 113-9.

56 McLeroy KR, Bibeau D, Steckler A, Glanz K. An ecological perspective on health promotion programs. Health Education Quarterly 1988; 15(4): 351-77.

57 Stokols D. Establishing and maintaining healthy environments. American Psychologist 1992; 47(1): 6-22.

58 Bere E, Veierod MB, Klepp KI. The Norwegian School Fruit Programme: evaluating paid vs. no-cost subscriptions. Preventive Medicine 2005; 41(2): 463-70.

59 Buzby JC, Guthrie JF, Kantor LS. Evaluation of the USDA Fruit and Vegetable Pilot Program: Report to Congress. Washington DC: Nutrition Research Program, Economic Research Service, US Department of Agriculture, 2003. 